DOI 10.31558/2307-2318.2019.4.4

УДК 338.465.4:378

Сидорова А.В., доктор економічних наук, професор, ДонНУ імені Василя Стуса

Кобідзе Н.Н., аспірант, ДонНУ імені Василя Стуса

\title{
ОСОБЛИВОСТІ ПОСЛУГ ВИЩОЇ ОСВІТИ В НОВІЙ ЕКОНОМІЩ
}

У статті розглянуто сутність і значення освітніх послуг на сучасному етапі розвитку економіки, яку називають новою. Розкрито сутність освітньої послуги, іiі значні відмінності в порівнянні з іншими послугами в контексті нової економіки, яка характеризується переважанням знань, інформаційних технологій, нових бізнеспроцесів, соціальних ініціатив над матеріальними активами. Визначено особливості освітніх послуг з точки зору змісту послуги, стандартів вищої освіти, спрямованості навчання, змісту програм, формування навчальних планів, суб'єктів навчального процесу, здатності до накопичення знань, умінь, навиків, співвідношення місця та часу виробництва й споживання освітніх послуг, ставлення до споживача, тривалості терміну надання послуг.

Ключові слова: освітня послуга, нова економіка, особливості освітніх послуг, компетентності, суб'єкти освітньої діяльності, стандарти вищої освіти.

Табл. - 1, Літ. - 12

\section{Сидорова А.В., Кобидзе Н.Н. \\ ОСОБЕННОСТИ УСЛУГ ВЫСШЕГО ОБРАЗОВАНИЯ В НОВОЙ ЭКОНОМИКЕ}

В статье рассмотрена сущность и значение образовательных услуг на современном этапе развития экономики, которую называют новой. Раскрыта сущность образовательной услуги, её значительные отличия по сравнению с другими услугами в контексте новой экономики, которая характеризуется преобладанием знаний, информационных технологий, новых бизнес-процессов, социальных инициатив над материальными активами. Определены особенности образовательных услуг с точки зрения содержания услуги, стандартов высшего образования, направленности обучения, содержания программ, формирования учебных планов, субъектов учебного процесса, способности к накоплению знаний, умений, навыков, соотношения места и времени производства и оказания образовательных услуг, отношения к потребителю, длительности срока предоставления услуг.

Ключевые слова: образовательная услуга, новая экономика, особенности образовательных услуг, компетентности, субъекты образовательной деятельности, стандарты высшего образования.

\section{Sydorova A., Kobidze N. \\ FEATURES OF HIGHER EDUCATION SERVICES IN THE NEW ECONOMY}

In the article essence and value of educational services are considered under modern economics. Essence of educational service as well as its differences compared to other services are exposed in the context of new economy, that is characterized by predominance of knowledge, information technologies, new business processes, social initiatives above material assets. The features of educational services are certain from the point of view of maintenance of service, standards of higher education, orientation of studies, maintenance of the programs, forming of curricula, subjects of educational process, capacity for the accumulation of 
knowledge, abilities, skills, correlation of place and time of educational services' production and consumption, attitude toward a consumer, duration of grant term.

Key words: educational service, new economy, features of educational services, competence, subjects of educational activity, standards of higher education.

Актуальність. Сучасний етап розвитку економіки отримав назву «нова економіка» або «економіка знань», тобто це економіка, яка базується не на екстенсивному споживанні вичерпних природних ресурсів, а на знаннях, на можливості генерувати знання, і в якій значну роль відіграє інтелектуальний капітал. Нова економіка - це сучасна економічна інфраструктура, що характеризується переважанням нематеріальних активів (знань, послуг) над матеріальними. Іншими словами, це економіка знань, нових інформаційних технологій, нових бізнес-процесів, що забезпечують конкурентоспроможність та лідерство. Важливу роль у новій економіці відіграють соціальні ініціативи, адже вони покликані формувати нових лідерів, які впливають на перебіг внутрішніх та міжнародних економічних процесів.

Знання та інформація в умовах нової економіки визначаються важливими ресурсами та джерелом багатства як окремої людини, формування ііі інтелектуального потенціалу, так і держави в цілому, яка підвищує таким чином людський капітал. Новою економікою також називають доступ, поширення та використання інформації в економічній діяльності за допомогою нових технологічних засобів. Отже, нова економіка характеризується своєю орієнтованістю на послуги та знання, зокрема на їхню передачу за допомогою нових технологій.

Основним фактором появи нової економіки стала зміна ролі інформації, котра стає найважливішим, більш легко керованим ресурсом і не вважається витратами. Особи, які не мають затребуваних знань і умінь, у новій економіці стають менш цінними для роботодавця. Тому необхідність отримання спеціальних компетентностей, які стали особливо цінними в новій економіці, змушує людину вчитися «впродовж життя». Ці суттєві зміни обумовлюють зростання ролі освіти як вищого пріоритету у системі державних цілей.

Освіта - це одна з секцій у сучасній моделі економіки, результатом діяльності якої, як і інших видів діяльності, $є$ створений продукт під назвою «освітня послуга». Згідно Класифікації видів економічної діяльності (КВЕД), освіта має свій власний класифікаційний код секції Р 85, 3 підсекцією освітня діяльність - Р 85.4; класом освітня діяльність у сфері вищої освіти - Р 85.42. Отже, освіта як вид економічної діяльності представляє собою сукупність установ та організацій, які здійснюють освітню діяльність, їх основною метою є створення і реалізація освітніх послуг, які під час реалізації стають товаром.

Порядок здійснення освітньої діяльності регулюється Законом України "Про освіту" (2014 р.) і Законом України «Про вищу освіту» (2017р.), якими встановлюється, що освітня послуга - це комплекс визначених законодавством, освітньою програмою і / або договором дій суб'єкта освітньої діяльності, мають певну вартість і спрямовані на досягнення здобувачем освіти очікуваних результатів навчання [1]. У наведеному в законі визначенні окреслено головні ознаки освітньої послуги, що заключаються, поперше, в тому, що послуга надається суб'єктом освітньої діяльності; по-друге, полягає в здійсненні суб'єктом освіти комплексу дій, встановлених законодавством, освітньою програмою і / або договором; по-третє, має на меті отримання певних результатів навчання здобувачем освіти.

Метою статті $\epsilon$ дослідження категорії «освітня послуга» та визначення 
особливостей послуги вищої освіти в новій економіці.

Для досягнення цієї мети досліджено сутність освітніх послуг як економічної категорії, уточнено іiї визначення, розглянуто особливості послуг вищої освіти. Дослідження сутності освітніх послуг знайшли відображення в наукових працях зарубіжних і вітчизняних учених-економістів. Серед українських науковців відмітимо В. Александрова [3], С.В. Багдік'яна [4], Г. Міщенко [9], А.Я. Дмитрів [7], А.В. Карпенка [8], Т.С. Оболенську [6], О. Панич [10], О.В. Прокопенко [5], Т.А. Ящук [12] та ін. У працях цих науковців з різних сторін досліджено економічну сутність послуги взагалі й освітньої послуги зокрема. В даній статті зосереджено увагу на особливостях послуг вищої освіти.

Виклад основного матеріалу дослідження. Процес розбудови суспільства знань пов'язаний 3 необхідністю формування сучасного інтелектуального потенціалу людського капіталу як основи конкурентоспроможності Української держави. Саме тому для створення економіки, основаної на знаннях, необхідно сприяти розвитку освітньої діяльності в країні, підвищенню якості освітніх послуг.

Для визначення особливостей послуг вищої освіти розглянемо і порівняємо її риси з сутністю послуги взагалі. Незважаючи на те, що в економічній літературі, в основному, склалося загальне уявлення про послуги, єдиного визначення сутності послуги немає. Пояснюється це тим, що різні автори розглядають іiі з різних сторін: як економічну категорію, як вид економічної діяльності, як процес, як результат діяльності, як товар.

У широкому сенсі послугу визначають як дію, що приносить користь іншому, тобто послуга - це результат, як правило, нематеріальний, щонайменше одного виду діяльності і який обов'язково утворюється у взаємодії постачальника та споживача.

У цьому визначенні підкреслюється, що послуга - це нематеріальний результат діяльності різних секторів економіки. Але деякі послуги матеріалізуються в зміненому стані особи чи об'єкта, на який направлено послугу. Більш широке розуміння послуги наведено в роботі [10,c.13]. Послуга - це вид діяльності, результатом якої є особливий продукт, призначений для продажу, як правило, в нематеріальній формі або який матеріалізується в зміненому стані об'єкта і задовольняє потреби особистості, колективу, суспільства в цілому. Послуги являють собою результат різнорідної діяльності, здійснюваної виробниками на замовлення споживачів. Отже, обов'язковою умовою надання послуги $є$ iii адресність, тобто наявність замовника (споживача). Матеріальна складова, що відображає змінений стан, присутня під час надання послуг транспорту (діяльність, у результаті якої відбувається зміна місця перебування особи чи об’єкту), послуги туризму (подорожі, відвідування країн, туристичних місць), послуги ремонту (зміна стану об'єкта), послуги охорони здоров'я, освіти (характеризують зміну стану особи) тощо.

Змінений стан особи в результаті надання послуги притаманний саме послугам освіти. Саме тому, як відмічається в статті [12,с.246] освітня послуга є специфічною формою, що має своїм результатом нематеріальний продукт у вигляді системи знань, інформації, вмінь, навичок, які передбачені робочими програмами дисциплін. Через певний період навчання вони будуть використовуватися здобувачем освіти 3 метою задоволення потреб людини і суспільства, тобто освітніми послугами є блага, які надаються не в вигляді речей, а в формі діяльності.

В. Александров відмічає, що освітня послуга - це організований процес навчання для одержання необхідних знань, навичок і вмінь. Це - особливий інтелектуальний товар, який надається стороною, що організує i здійснює процес навчання, та отримується іншою стороною, яка може бути одночасно і учнем, і контролером якості 
послуги, і платником за неї [3]. Автор використовує у даному випадку категорії «процес» і «товар».

Освітні послуги як процес і результат визначаються в роботі С.В. Багдік'яна, який пише, що освітні послуги можна охарактеризувати як цілеспрямований систематичний процес передачі та отримання знань, інформації, вмінь і навичок та результат інтелектуального, культурного, духовного, соціально-економічного розвитку суспільства та держави [4].

На думку Т. Оболенської, освітня послуга - специфічний товар, який задовольняє потребу людини в набутті певних знань, навичок і вмінь для їхнього подальшого використання в професійній діяльності [6,c.133]. Отже, у цьому визначенні відмічається, що освітня послуга $є$ товаром, призначеним для продажу.

Освітню послугу як «сукупність корисних властивостей, які повинні задовольнити пов'язані з одержанням кваліфікації потреби споживачів» характеризує у своєї статті Дмитрів А.Я. і відмічає, що освітні послуги задовольняють особистісні (кінцевий споживач), колективні (підприємства-роботодавці) та суспільні (держава, суспільство) потреби [7]. Тобто він підкреслює тривимірну сутність освітньої послуги та надає визначення послуги вищої освіти як «процес», але за такими аспектами:

1) з погляду особистості - це процес передачі кінцевому споживачеві сукупності знань, вмінь та навичок професійного змісту, які необхідні для задоволення його особистих потреб в отриманні професії, а також самовдосконаленні та самоствердженні; цей процес здійснюється за тісної взаємодії зі споживачем відповідно до встановленої програми та за певною формою (денна, заочна, вечірня або дистанційна) [7] ;

Зауважимо, що освітня послуга як результат процесу - це продукт спільної праці викладачів та здобувачів вищої освіти, тому з цієї точки зору система відношень між ними розглядається як процес, забезпечений необхідними матеріальними й нематеріальними ресурсами задля здійснення навчання та оволодіння здобувачем освіти програмних результатів.

2) 3 погляду закладу освіти - це процес фахової підготовки, підвищення кваліфікації або перепідготовки персоналу, які необхідні для забезпечення його подальшої працездатності, підтримки конкурентоздатності й розвитку людського капіталу в змінному ринковому середовищі;

3) 3 погляду держави - це процес, який забезпечує формування й розвиток особистісного та інтелектуального потенціалу суспільства. Проте автор не враховує, що в сучасних умовах в освітню діяльність включається роботодавець.

3 іншої точки зору розглядає характеристику освітніх послуг Т.Є. Оболенська, яка відмічає, що у теорії маркетингу освітніх послуг створено чотиривимірну систему характеристик, притаманних послугам, а саме: невідчутність (нематеріальність), невіддільність, мінливість (або іiі ще називають непостійністю) та незбереженість [6].

У роботі Г. Міщенка відмічається, що «товаром вищого навчального закладу можна вважати випускника і диплом як документ, що гарантує певні дивіденди від інвестованих матеріальних і моральних зусиль» [9]. Але з таким твердженням не можна погодитись.

Зазначимо, що випускник ЗВО не може бути товаром, він виступає носієм загальних і спеціальних (професійних) компетентностей, передбачених освітньою програмою, і які інтегруються в програмних результатах навчання (ПРН). Заявлений Г. Міщенком підхід пояснюється тим, що на ринку праці дійсно часто конкурують дипломи закладів вищої освіти, не дивлячись на те, що, по-перше, випускники ЗВО мають різний рівень теоретичних знань, умінь і практичних навичок, по-друге, працюють вони не завжди за своїм напрямом освіти (або освітньою програмою), для 
яких, відповідно стандарту вищої освіти, передбачається різний перелік компетентностей і програмних результатів навчання (ПРН). Отже, освітня послуга складна категорія, котра характеризує різні сторони освітнього процесу.

У новій економіці змінюється система підготовки здобувачів освіти. Підготовка здобувачів вищої освіти в сучасних умовах усе більше орієнтується не на фахівця в галузі конкретної науки, а на оволодіння компетентностями професії й посади, які прописані в освітній програмі, розробленій згідно державному стандарту.

Стандарти вищої освіти, розроблені в Україні в період з 2016 до 2018 р., $\epsilon$ стандартами нового покоління. Вони відповідають вимогам Болонського процесу i базуються на компетентністному підході. У стандартах не встановлюють перелік нормативних дисциплін (як це було у попередніх стандартах) і вибіркових дисциплін, що забезпечує автономію університетів. Завдяки цьому створюються передумови для широкого розмаїття освітніх програм [11]. Очікується, що такі стандарти будуть орієнтувати викладачів та студентів на конкретні результати, залишаючи їм достатньо самостійності у визначенні шляхів досягнення результатів навчання. Підтвердити останню тезу можна словами Адама Сміта, що час, витрачений на навчання, $\epsilon$ значно продуктивнішим ніж час, коли людина вже безпосередньо використовує в процесі навчання набуті знання, вміння, навички і досвід.

Сьогодні стандартами вищої освіти передбачається розробка освітніх програм, у яких наведено необхідний перелік загальних і спеціальних (професійних або фахових) компетентностей, яких повинні набути здобувачі вищої освіти, щоб оволодіти програмними результатами навчання (ПРН).

Як будь-який вид економічної діяльності, діяльність у сфері вищої освіти утворює особливий продукт (освітню послугу), тобто результат діяльності. Продуктом діяльності закладу вищої освіти необхідно вважати не випускника, а перелік інтегральної, загальних i спеціальних компетентностей і програмних результатів, якими повинен оволодіти здобувач освіти під час навчання, тобто в процесі споживання освітніх послуг, а диплом про вищу освіту $є$ матеріальним проявом освітньої діяльності - це документ, який підтверджує, що фахівець отримав цей перелік.

Отже, в сучасних умовах освітню послугу, яку надає ЗВО, пропонується визначити наступним чином: послуга вищої освіти - ие особливий нематеріальний продукт, який $\epsilon$ результатом процесу навчання, направленого на оволодіння інтегральною, загальними й спеціальними компетентностями та програмними результатами навчання (ПРН), $i$ який задовольняє потреби особистості, колективу та суспільства.

Уточнення визначення освітньої послуги дозволяє виокремити іiї особливості в новій економіці. Перш за все, відмітимо систему загальновідомих характеристик, притаманних послугам взагалі, а саме: нематеріальність, неможливість зберігати та накопичувати послуги, непостійну якість надання, невіддільність виробника й споживача. До переліченого можна додати таку характеристику, як «співпадіння місця та часу виробництва і споживання послуг». Проте, не всі характеристики послуг притаманні освітнім послугам.

Для освітніх послуг характерні нематеріальність, тобто освітні послуги не можна відчути або побачити; невіддільність викладача й студента, бо вони знаходяться в одній аудиторії або в режимі on-line в той самий час; освітнім послугам притаманна непостійна якість надання, оскільки викладачі мають різний рівень кваліфікації, а здобувачі освіти - різний рівень підготовки, різний рівень сприйняття нового, крім того, впливають бажання й здатності здобувача освіти оволодіти компетентностями, якість і структура 
освітньої програми, залежність від забезпеченості процесу сучасним лабораторним обладнанням, комп’ютерними програмними продуктами та від інших умов.

Разом $з$ тим, отримані компетентності й програмні результати навчання не тільки зберігаються, але й накопичуються в результаті перепідготовки, підвищення кваліфікації, отримання другої освіти тощо, або з часом втрачаються, або морально застарівають. Слід підкреслити, що в умовах нової економіки невідділеність викладача від споживача (здобувача освіти) також змінюється, оскільки крім двох суб'єктів навчального процесу з'являється ще один суб'єкт - роботодавець, який є кінцевим споживачем набутих потенціальним працівником компетентностей. Узагальнення викладеного дозволяє порівняти особливості освітніх послуг у різних умовах (табл.1).

\section{Особливості послуг вищої освіти у новій економіці*}

\begin{tabular}{|c|c|c|c|}
\hline № & $\begin{array}{c}\text { Властивості та особливості } \\
\text { послуг }\end{array}$ & У традиційній економіці & У новій економіці \\
\hline 1 & За освітнім стандартом & $\begin{array}{lr}\text { Сутність освітньої послуги за } \\
\text { стандартом } & \text { визначалась на } \\
\text { основі } & \text { нормативних } \\
\text { дисциплін } & \\
\end{array}$ & $\begin{array}{l}\text { Поняття нормативних дисциплін } \\
\text { скасовано. Сутність визначається } \\
\text { на основі компетентнісного } \\
\text { підходу }\end{array}$ \\
\hline 2 & За змістом & $\begin{array}{l}\text { Система знань, умінь i } \\
\text { навичок }\end{array}$ & $\begin{array}{lrr}\text { Сукупність } & \text { інтегральної, } \\
\text { загальних } & \text { i } & \text { спеціальних } \\
\begin{array}{l}\text { компетентностей } \\
\text { результатів }\end{array} & \text { програмних } \\
\end{array}$ \\
\hline 3 & За спрямованістю навчання & \begin{tabular}{lrr} 
Підготовка & \multicolumn{2}{c}{ фахівця } \\
орієнтацією & на & оволодіння \\
фаховою наукою & \\
\end{tabular} & $\begin{array}{l}\text { Підготовка фахівця з орієнтацією } \\
\text { на професію та посаду }\end{array}$ \\
\hline 4 & $\begin{array}{l}\text { За змістом освітньої } \\
\text { програми }\end{array}$ & $\begin{array}{l}\begin{array}{l}\text { Нормативні } \\
\text { дисципліни }\end{array} \\
\end{array}$ & $\begin{array}{l}\text { Фундаментальні, } \\
\text { вибіркові, спеціальні }\end{array}$ \\
\hline 5 & $\begin{array}{lr}\text { За } & \text { формуванням } \\
\text { навчального робочого плану }\end{array}$ & $\begin{array}{l}\text { Визначення нормативних i } \\
\text { вибіркових дисциплін під час } \\
\text { складання плану }\end{array}$ & $\begin{array}{l}\text { Визначення } \\
\text { фундаментальних і професійних. } \\
\text { Вибіркові дисципліни обирають } \\
\text { самі студенти }\end{array}$ \\
\hline 6 & навчального & Виробник послуги і споживач & $\begin{array}{l}\text { Виробник послуги, споживач i } \\
\text { роботодавець }\end{array}$ \\
\hline 7 & $\begin{array}{l}\text { Здатність до накопичення } \\
\text { послуг }\end{array}$ & $\begin{array}{lr}\text { Поступова } & \text { втрата } \\
\text { теоретичних } & \text { знань i } \\
\text { накопичення } & \text { практичних } \\
\text { навиків, «застаріння знань» }\end{array}$ & $\begin{array}{l}\text { Оволодіння компетентностями й } \\
\text { програмними результатами } \\
\text { вимагають постійного оновлення } \\
\text { та навчання «впродовж життя» }\end{array}$ \\
\hline 8 & $\begin{array}{l}\text { Співпадіння місця та часу } \\
\text { виробництва й споживання } \\
\text { послуг }\end{array}$ & $\begin{array}{l}\text { Співпадіння місця та часу } \\
\text { виробництва й споживання } \\
\text { послуг характерне тільки під } \\
\text { час занять }\end{array}$ & $\begin{array}{l}\text { У новій економіці поширюється } \\
\text { дистанційне навчання, що } \\
\text { приводить до неспівпадіння місця } \\
\text { виробництва та споживання } \\
\text { послуг }\end{array}$ \\
\hline 9 & Ставлення до споживача & $\begin{array}{l}\text { Після продажу освітніх послуг } \\
\text { відносини між ЗВО та } \\
\text { роботодавцем закінчуються }\end{array}$ & $\begin{array}{l}\text { Після продажу освітніх послуг } \\
\text { відносини між } \text { зВО і } \\
\text { роботодавцем продовжуються } \\
\text { через участь у розробці та } \\
\text { обговоренні } \\
\text { стажування, } \\
\text { спеціалістів }\end{array}$ \\
\hline 10 & $\begin{array}{l}\text { Тривалий термін } \\
\text { надання освітніх послуг }\end{array}$ & Характерна ознака & Характерна ознака \\
\hline
\end{tabular}

*Власна розробка 
Для більшості послуг характерне співпадіння місця і часу виробництва та споживання, тобто зазвичай послуги споживаються під час їх надання, але формування компетентностей потребує, по-перше, самостійного опрацювання навчального матеріалу та додаткового часу, в результаті час споживання відсувається; по-друге, неспівпадіння виникає в зв'язку з тим, що здобувач освіти повинен бути працевлаштованим, якщо цього немає, його компетентності залишуться не затребуваними. Якщо здобувач освіти взагалі не працює за фахом, або буде працювати в іншій галузі, то його компетентності, що прописані в стандартах спеціальностей і освітніх програм, не затребувані й не реалізуються.

Планом пріоритетних дій Уряду України на 2018 рік передбачалося підготувати понад 150 стандартів за різними спеціальностями для різних рівнів вищої освіти. Загальна кількість стандартів визначається переліком галузей знань і спеціальностей, прийнятим у 2015 р., за якими здійснюється підготовка здобувачів вищої освіти [2]. Згідно з цим документом, налічується 293 спеціальності, за якими сьогодні виконується підготовка здобувачів вищої освіти і, відповідно, мають бути підготовлені стандарти, в яких після обговорень 3 громадськістю затверджуються загальні й спеціальні компетентності. Станом на грудень 2018 року було розроблено 108 стандартів рівня «бакалавр», 50 магістерських та 20 рівня «доктор філософії» [11].

Висновки. Основними суб'єктами ринкових відносин нової економіки в освіті $€$ виробники освітніх послуг (заклади вищої освіти, фізичні особи, які надають освітні послуги), споживачі послуг (здобувачі освіти) та роботодавці (кінцеві споживачі: підприємства, фізичні і юридичні особи, організації). Узагальнення різних визначень дає змогу стверджувати, що освітня послуга $є$ результатом освітньої діяльності, в якій відображено складні економічні відносини між виробником послуг, здобувачем освіти й роботодавцем.

Носієм компетентностей $є$ особистість, і лише від неї залежить, наскільки ефективно надані освітні послуги будуть використані для досягнення поставлених цілей та завдань. На ринку праці випускник університету стає представником закладу вищої освіти, його іміджу і якості надання освітніх послуг. Послуги вищої освіти мають певні особливості 3 неоднозначними характеристиками, розуміння яких $\epsilon$ чинником поліпшення іміджу закладу та управління попитом на послуги вищої освіти. Корисний результат освітніх послуг виявляється лише через тривалий час, а його вимір здійснюється не безпосередньо, а з використанням непрямих показників.

\section{СПИСОК ВИКОРИСТАНИХ ДЖЕРЕЛ}

1. Закон України «Про вищу освіту» https://zakon.rada.gov.ua/laws/show/1556-18

2. Стандарти і рекомендації щодо забезпечення якості в Свропейському просторі вищої освіти. - К: ТОВ «ЦС», 2015. - С. 17-25.

3. Александров В. Освітня послуга: суть та моделі якості // Економіка України, 2007. №3 - С. 53-60

4. Багдік'ян С.В. Освітні послуги: дослідження поняття, класифікація, базові характеристики // Економіка, Менеджмент, Підприємництво. - 2010. - № 22 (1). - С. 97 100

5. Маркетинг образовательных услуг: монография / Под общ. ред. д-ра экон. наук, проф. О.В. Прокопенко. - Ruda Śląska : «Drukarnia i Studio Graficzne Omnidium», 2016. - 168 c. 6. Оболенська Т.Є. Маркетинг освітніх послуг: вітчизняний і зарубіжний досвід. - К.: KHEУ, 2001. - $208 \mathrm{c}$. 
7. Дмитрів А.Я. Характеристика особливостей освітньої послуги з погляду маркетингу. Національний університет “Львівська політехніка", 2010. http://ena.lp.edu.ua

8. Карпенко А.В. Розвиток інтелектуальних активів людського потенціалу: теорія та практика: монографія.- Запоріжжя: ФОП В.М. Мокшанов, 2018.-510 с.

9. Міщенко Г. Маркетинг і вища освіта // Вісник Книжкової палати - №8 - 2004.

10. Сидорова А.В. Методы анализа и прогнозирования развития сферы услуг: монография.- Донецк, 2002.- 239 с.

11. Панич О. Система підготовки стандартів вищої освіти і перспективи іiі вдосконалення./ Матеріали конференції «Розбудова системи забезпечення якості вищої освіти в Україні»: Київський Національний торговельно-економічний університет). 1112 червня $2019 \mathrm{p}$.

12. Ящук Т.А. Ринок освітніх послуг: сутність та тенденції розвитку //Інноваційна економіка № 8,2013, с. 246-249. 